DOI: $10.15421 / 231822$

\title{
Методологічні принципи як норми етичного і професійного кодексу історика
}

Кривчик Г.Г.

Дніпровський національний університет залізничного транспорту імені академіка В. Лазаряна

Показано взаємозв'язок основних етичних норм із загальнонауковими й спеціальними історичними методологічними принципами, уточнено визначення й наведено приклади застосування останніх, вміщено критику щодо порушення етики й наукової методології.

Ключові слова: доброчесність; істина; всебічність; системність; конкретність; об' єктивність; діалектика; історизм; джерела; художність

Показана взаимосвязь основных этических норм с общенаучными и специальными историческими методологическими принципами, уточнены определения и приведены примеры применения последних, содержится критика нарушения этики и научной методологии.

Ключевые слова: добродетельность; истина; системность; конкретность; объективность; диалектика; историзм; источники; художественность

If historical methods are the tools of the researcher, then the principles of the historical research are a kind of the ethical and professional code of a historian. It consists of a number of professional principles which are based on: a) fundamental human ethical norms; b) scientific ethics; c) the special features of a particular science.

In its turn, the general scientific principles are applied in various scientific fields, especially in the historical sciences. Among them are 1) the principle of consistency, which involves the study and consideration of all facts and data, the prevention of pulling out only those facts that meet the author's concept. For a historian this means the systematization, evaluation and use of the entire complex of historical sources. That means that a historian must not operate separate, chosen, and profitable facts, but the complex of different and sometimes contradictory facts, because even the most obvious facts, taken out of the context of events, can give the incorrect picture of the past. 2) The principle of objectivity, which is used mainly in the humanities, involves the non-biased attitude to facts and removal from the political conjuncture, and at the same time considering the subjective component of any historical works and written sources. It is necessary to take into account the objective reality: no matter how honest and principled a historian is, in any case, political, national, ideological, religious, party and other preferences and features will be reflected in his works. As far as the specificity of the historical science is that its object is our past, then the purely historical principle is only the principle of historicism, which has two components. Firstly, analysis of facts, phenomena, behavior of historical characters, taking into account a particular historical epoch, its laws, ethical norms, and traditions. Secondly, the recreation of the spirit of a particular epoch and penetration into the atmosphere in which phenomena, events and processes took place. Therefore, in a certain sense historical principles act as different facets of the ideal to which a historian should strive.

Keywords: scientific dignity; truth; consistency; systematization; objectivism; dialectic; sources; artistic 
Спонукальним мотивом написання цього матеріалу став перегляд низки дисертаційних робіт з історичних дисциплін. Привернуло до себе увагу те, як молоді вчені визначають методологічні принципи своїх досліджень. Виникла підозра, що більшість із них роблять це лише через те, що «так вимагається», а не заради пояснення своїх світоглядних і творчих підходів, як це має бути. Відтак, відповідні підрозділи часто написані формально, схожі одне на одне, буцімто написані під копірку. Складається враження, що дехто з їх авторів взагалі не розуміє про що пише.

Здавалось би, на сьогодні ми маємо велику кількість посібників із методології історії, написаних досвідченими й авторитетними вченими. Бери й читай їх. Учись розуму в М. А. Барга [1] I. Я. Біска [3], В. Ф. Коломійцева [11], А. В. Санцевича [18], I. Д. Ковальченка[10] та інших наших корифеїв, які у свій час, поза сумнівом, відіграли величезну роль у розвитку вітчизняної історичної науки. Однак слід визнати, що більшість наявних праць із методології історичних досліджень створені в радянські часи, містять ідеологічні штампи, на кшталт класових підходів і пріоритету над іншими принципу комуністичної партійності; деякі з книг написані дещо зарозуміло й мовою, яка, правду кажучи, не у всіх читачів викликає бажання осмислити їх зміст. Тож стала очевидною необхідність відновлення методологічних досліджень з урахуванням набутого досвіду й нових завдань, що повстали перед історичними науками. Ніяким чином не претендуючи на істину в останній інстанції, автор даної методологічної розвідки лише висловлює власне бачення проблеми, яка полягає в необхідності ув'язати методологічні принципи історичної науки із загальнолюдськими й загальнонауковими цінностями і нормами. Адже якщо історичні методи - це інструментарій дослідника, то принципи історичного дослідження - це своєрідний етичний кодекс історика. Він складється 3 низки професійних принципів, які базуються на: а) основоположних людських етичних нормах; б) науковій етиці; в) на власній науковій специфіці.

Як відомо, загальнолюдські етичні норми або принципи сформульовані ще в Біблії. Частина 3 цих норм трансформується в наукові принципи, які знайшли відображення в Етичному кодексі вченогоУкраїни, який був прийнятий на Загальних зборах НАНУ 15 квітня 2009 р. [4]. Так, з другої та п’ятої заповідей Закону Божого - «Не роби собі кумира» та «Шануй батька твого і матір твою» [7, с. 519] - випливають наукові принципи верховенства істини 
(«Платон мені друг, але істина дорожча»), деідеологізації наукової творчості, самостійного мислення, поєднання шанобливого ставлення до наукових корифеїв, до своїх попередників й до вчителів, тобто до всіх своїх духовних батьків, з прагненням знайти свій власний шлях у науці. Слід відстоювати свою точку зору. Навіть тоді, коли вона суперечить загально прийнятій думці. «Что бы я да не постоял за то, что считаю правдой и истиной! ... Хоть бы весь мир провалился, я не склоню шеи под ярмо... Я хочу смело глядеть в глаза своим мальчикам, когда они вырастут свободными людьми». - Ці слова доктора Стокмана з відомої драми Генріка Ібсена «Ворог народу» можна визнати ще одним моральним кредо справжнього вченого [5, 569-570]. Сьома заповідь - «Не чини перелюбу» [5, с. 519] - виступає в науковій сфері як принцип наукової гідності: не прода-вай наукову совість, бережи бездоганну наукову чесність на всіх стадіях наукового дослідження. Восьма заповідь - «Не кради» виступає як науковий принцип неприпустимості наукового плагіату, шахрайства, піратства, про що також йдеться в Кодексі вченогоУкраїни. Зазначний принцип $є$ актуальним і для історичних наук.

На жаль, ми занадто часто стикаємося 3 порушенням зазначених норм, зокрема в історичній науці. Це відбивається в різних формах, передусім у прагненні деяких науковців вічно перебувати в мейстримі сучасної офіційної ідеології, догодити владі. Іноді ціною втрати наукової честі. Прикладом цього можуть служити діаметрально протилежні судження щодо національного питання в Україні радянської доби. Одна оцінка: «Украинские буржуазные националисты, будучи злейшими врагами интернационализма и братского союза украинского народа с русским, стремились отравить сознание трудящихся ядом национализма, привив им чувство вражды к русскому народу от классовой борьбы против угнетения и тем самым подчинить корыстным классовым интересам буржуазии и помещиков» [20, с. 30-31]. Край протилежне твердження: «Всю діяльність ОУН-УПА підкорили боротьбі за утворення Української Самостійної Соборної держави»... Натомість «Тоталітарний комуністичний режим завдав великої шкоди історичній пам'яті українського народу, історичній спадкоємності декількох поколінь. Ідеологи цього режиму усвідомлювали, що незнання народом свого історичного коріння робить людину байдужою до долі народу, призводить до манкуртизму, спотворює і знищує національну свідомість, робить іiі податливою до всіляких спекуляцій» [20, с. 34]. Важко повірити, але обидва судження висловлені однією людиною 
- знаним українським істориком А. М. Черненком (1926-2000). Коли ж учений був щирим і говорив істину: в 1979 р. чи в 1994, коли писав ці рядки? На жаль, прикладів подібних «реінкарнацій» можна навести чимало. Справа, звичайно, не в істинності першого чи другого суджень. У науці має існувати плюралізм думок. Певна річ, історик, як і кожна людина, може протягом життя вносити певні корективи у свої погляди, сумніватися, навіть помилятися в чомусь, щоб потім визнавати й виправляти своїпомилки. Взагалі душевні терзання - це нормальний стан не тільки науковця, але й будь-якого homo sapiens. Зрештою, й первоверховні святі апостоли Петро і Павло не народилися проповідниками християнської віри. Але ставши ними, вони зазнали утисків і гонінь з боку влади і тодішнього суспільства. Через їхню віру одного розіп'яли на хресті, другому відтяли голову [7, с. 339]. Погано, коли у вченого відбувається радикальна зміна думок на догоду кон'юнктурі чи мамоні. Але що особливо прикро, так це те, що подібні прояви лукавства не знаходять осуду в науковому співтоваристві. Кон'юнктурники залишаються рукопожатними в ньому.

Як відомо, останніми роками у вітчизняному освітньому й науковому просторі набула характеру епідемії й інша соціальна хвороба - плагіат. Дошки оголошень у великих містах буквально рясніють закликами: «Допоможемо у написанні курсових і дипломних робіт, кадидатських і докторських дисертацій». Однак приклади особливо злісного плагіату демонструють не стільки науковці-початківці, скільки саме ті, хто за своїм становищем зобов'язані бути взірцем доброчесності. Періодично виникають скандали, пов'язані з плагіатом можновладців. Так, плагіатом була визнана книга колишнього президента і за сумісництвом «проффесора» В. Ф. Януковича «Opportunity Ukraine», що була надрукована в 2011 р. в Австрії. За даними тижневика «Тиждень. UA», за підписом президента видано не лише гучні ідеї, а скомпільовані цілі абзаци з текстів, які раніше виходили за підписом інших: відомого журналіста В'ячеслава Піховшика, політиків Тараса Стецьківа, Василя Волги та ін. [17]. Плагіатом зганьбив себе колишній голова Верховної Ради України, доктор історичних наук, професор, академік НАНУ, автор понад 570 (!) публікацій В. М. Литвин, який опублікував у 2002 р. в газеті «Факты и комментарии» під назвою «Гражданское общество: мифы и реальность» переклад статті Томаса Карозерса, що була надрукована раніше в журналі «Forein Polisy» [22, p. 18-29]. Сам історик пізніше виправдовувався на сторінках часопису «Фокус»: мовляв, 
йому підготували матеріал його помічники, а він лише відредагував текст [12]. Однак даний випадок виявився непоодиноким в «науковій творчості» академіка. До речі, плагіат часто пов'язаний 3 іншим характерним проявом наукового шахрайства - використанням можновладцями чи багатіями наукових найманців для написання дисертацій та інших наукових праць. Ні для кого не секрет, що особливо в ціні фахівці в галузях економіки, юриспруденції, державного управління, тобто ті, хто може надати інтелектульні послуги «слугам народу» й посприяти таким чином їх кар'єрному зростанню.

У свою чергу, загальнонаукові принципи застовуються в різних наукових галузях, зокрема в історичних науках. Серед них принцип системності, який передбачає вивчення й урахування всіх елементів, фактів і даних, недопущення висмикування лише тих фактів, що можуть підтвердити авторську концепцію. Для історика це означає систематизацію, оцінювання й використання всього комплексу історичних джерел. Слід оперувати не поодинокими, підібраними, вигідними фактами, а всією сукупністю різноманітних, суперечливих фактів, адже навіть найбільш очевидні, здавалося б, факти, вихоплені з контексту подій, можуть дати хибну картину.

У зв’язку з цим варто згадати одну досить кумедну історію, що розповів російський письменник В. В. Вересаєв. У середині 1920-х pp. на засіданні одного з московських літературних товариств якийсь молодий пушкініст виступив 3 доповіддю про творчість О. С. Пушкіна. Цитуючи у своїй доповіді поета, він хотів довести, що той був справжнісіньким більшовиком і предтечею Жовтневої революції. Не дивно, що така дурня не могла не викликати обурення присутніх. Тоді взяв слово письменник А. Насимович і сказав: «Товарищи! Я очень удивлен нападками, которым тут подвергся докладчик. Все, что он говорит о коммунизме Пушкина, настолько бесспорно, что об этом не может быть никакого разговора. Конечно, Пушкин был чистейший большевик. Я только удивляюсь, что докладчик не привел еще главной цитаты из Пушкина, которая сразу заставит умолкнуть всех возражателей. Вспомните, что сказал Пушкин: «Октябрь уж наступил...» [3, с. 339].

Чи не так, як той «пушкініст», оперуюють окремими цитатами, фактами, або джерелами деякі науковці. Характерний приклад такого підходу в науці репрезентує книга академіка РАН А. Т. Фоменка та Г. В. Носовського «Русь і Рим. Чи правильно ми розуміємо історію Європи і Азії?», в якій містяться «сенсаційні відкриття»: виявляється Христос народився в ХІ столітті після Р. Х., Орда була 274 
регулярним військом Руської держави, Ярослав Мудрий, Іван Калита і хан Батий - це одна людина, англійська історія насправді описує історію Риму... [15]. Або ось інший курйоз, що став можливим також через використання окремих історичних джерел. Один із вітчизняних істориків-аматорів напередодні 100-річчя Жовтневої революції надрукував у популярному тижневику «2000» статтю, в якій теж цілком серйозно стверджувалося, що насправді ніякої Жовтневої революції не було, адже в жодній провідній петроградській газеті тих днів він не знайшов згадки про штурм Зимового палацу, про постріл крейсера «Аврора», Жовтневу революцію [16]. На що редакція тижневика у своєму коментарі цілком слушно вказала автору на те, що повідомлення про Жовтневий переворот були в інших джерелах, зокрема, в газетах «Русское слово» (25 жовтня), «Рабочий путь» (26 жовтня), в ташкентській «Нашій газеті» (8 листопада), а також в зарубіжних виданнях «Юманіте», «Курьер Варшавски» тощо [16].

Принцип системності має взаємодіяти з іншими наріжними методо-логічними принципами - всебічності, згідно з яким кожен предмет слід розглядати з усіх сторін, та об'єктивності, який передбачає неупереджене ставлення до фактів, безпристрасність оцінок, уникнення політичної, ідеологічної, релігійно-конфесійної та іншої кон'юнктури і водночас врахування суб'єктивної складової будьяких історичних творів і письмових джерел. Історик не прокурор i навіть не суддя, він скоріше уподібнюється патологоанатому, для якого головним $є$ докопатися до істини шляхом препарування мертвого тіла, тобто того, що вже не можна оживити, й при цьому необхідно залишатися безпристрасним і неупередженим. Однак споживачам наукового продукту, що створений істориком, слід бути пильними, тобто враховувати об'єктивну реальність: яким би чесним і принциповим не був історик, як би він не прагнув до об'єктивності - усе одно в його творах відбиватимуться політичні, національні, ідеологічні, релігійні, партійні та інші уподобання, особливості, симпатії та антипатії. Як влучно висловився В. О. Ключевський в «Методології руської історії»: «Выбор и оценка явлений у историка-магометанина необходимо должны быть не те, какие встречаем у историка-христианина» [9, с. 72]. У цьому зв'язку, до речі, здаються цілком зрозумілими різні, часом протилежні, історичні оцінки важливих історичних подій на переважно католицькому й греко-католицькому Заході й на православному сході України. Скажімо, таких подій, як підписання Берестейської унії 1596 р., заснування Катеринослава, Друга світова війна, діяльність ОУН тощо. 
Слід також відмітити особливу роль у науковому дослідженні діалектики, яка виступає одночасно в якості загальнонаукового методу і важливого наукового принципу. Як метод вона є одним 3 інструментів, що допомагає досліднику бути об'єктивним, розкривати саму сутність явищ і процесів, дослідити їх складність, суперечливий характер, їхнє минуле і сучасне. Виступаючи в якості принципу, діалектика $\epsilon$ імперативом, що вимагає від ученого досліджувати будь-яке явище в його постійному русі, джерелом якого $є$ протиріччя, їх єдність та боротьба. Також слід взяти до уваги й те, що відповідно до третього гегелівського закону діалектики - скасування скасування - наші оціночні судження змінюються по мірі накопичення наших знань, причому часом до протилежних, для того, щоб вийти потім на попередні, але вже більш глибокі, об'єктивні, синтетичні погляди та переконання.

Особливе значення діалектика має для історика, вимагає від нього дослідження того чи іншого суспільства в множинності його укладів, зміні комбінацій укладів, у черговості еволюційного й революційного розвитку суспільства; характеризуючи діяльність окремих історичних персон, діалектик має вказати на позитивні й негативні якості особистості, на їх внутрішній розвиток і зовнішні обставини, за яких вони формувалися. Подібні чесноти, поза сумнівом, були у Д. І. Яворницького, що, зокрема, видно з того, як він характеризував гетьмана I. Мазепу в своїй «Історії запорозьких козаків»: «Гетман Мазепа - натура весьма сложная и потому трудно доступная для понимания... В общем характере Мазепы сочетались черты частного человека, черты неприятные, своекорыстные и отталкивающие, и черты общественного малороссийского деятеля, хотевшего видеть свою родину независимой в политическом отношении». I далі історик пояснив, що означені якості Мазепи формувалися при дворі польського короля, «відомого епікурейця та любодія», на службі у Дорошенка, що висунув ідею відторгнення України від Росії, у Самойловича, що був добре відомий як безмірний користолюб і стяжатель. За словами Яворницького: Мазепа придбав у Польщі «светский лоск и латинское образование, усвоил польский образ мыслей; в то же время, имея кривую душу, лживое сердце, он мог усвоить тонкое, но бессердечное и фальшивое к людям отношение... мог развить в себе инстинкт стяжания и презрительного отношения к людям, и все это прикрывать наружным благочестием, кажущейся преданностью своим патронам и благодетелям, видимой во всем откровенностью, напускной веселостью и природным юмором» [21, с. 287]. 
Крім загальнонаукових методологічних принципів, є принципи, що належать лише до певної наукової галузі. Так, до суто історичних методологічних принципів зарахуємо ті принципи, що випливають із сутності історичної науки. По-переше, це принцип конкретності, за яким кожну історичну подію слід розглядати в конкретній формі, в конкректному просторі й часі. По-друге, це принцип опори на історичні джерела, за яким історик зобов'язаний формулювати свої судження й висновки на основі історичних джерел. По-третє, оскільки основна специфіка історичної науки полягає в тому, що ії об'єктом $\epsilon$ минуле, то головним історичним принципом $є$ принцип історизму, який у свою чергу має дві складові. По-перше, це аналіз фактів, явищ, поведінки історичних персонажів з урахуванням конкретної історичної епохи, іiї законів, етичних норм, традицій, про що влучно висловився М. М. Карамзін, оцінюючи діяльність кн. Ольги: «... мы должны судить о Героях Истории по обычаям и нравам их времени» $[8$, с. 100]. Порушення цього принципу не тільки призводить до неправильних і упереджених наукових висновків, але й часто-густо використовується в політичних цілях, що дає підстави іменувати історію політикою, що повернута в минуле. По-друге, це відтворення духу тієї чи іншої епохи, проникнення в атмосферу, в якій відбувалися явища, події й процеси. Означеним принципом володіли й керувалися корифеї російської та української історичної науки, зокрема В. О. Ключевський, С. М. Соловйов, М. К. Любавський та ін. Ось, наприклад, як філігранно, лаконічно і водночас яскраво історично М. К. Любавський зображує княжий суд в Київській Русі. «Местом собраний служили обширные дворы или площади около церквей или на рынках, могущие вместить значительную народную толпу. В Киеве вече собирались на Ярославле дворе, у св. Софии, на торговище у Туровой божницы... При обсуждении дел собравшиеся или стояли, или садились на особые скамейки. В моменты обострения отношений между князем и населением на вече собирались на конях, вооруженные. В 1146 году киевляне, недовольные тиунами великого Всеволода Ольговича, потребовали от князя Святослава, его брата, чтобы князь отставил их и сам судил. Они явились к Туровой божнице все на конях, куда приехал и князь Святослав. Князь согласился на предъявленное к нему требование, «и съсед с коня, на том целова хрест к ним; кияне же вси, съседше с конь, начаша молвити (Ипатьев., под 1146)» [13, с. 155].

На жаль, за радянської доби у вітчизняній історіографії хоча й наголошувалося на необхідності дотримання принципу історизму, 
однак насправді мало хто 3 нас керувався ним. Як признавався протопіп Аввакум: «И аз есмь человек грешник» [6, с. 4]. Ми не стільки прагнули зобразити минуле життя, скільки переймалися констатацією фактів і визначенням рушійних сил, причин, передумов, наслідків тих чи інших подій. Значною мірою ігнорувалися художньо-літературні вимоги до історичних творів. Якось було забуто, що історія - це не тільки дослідження історичних фактів і процесів, а, насамперед, зображення суспільства в певну історичну епоху, написання портретів «Героїв Історії». Недооцінювалися фактори емоційного впливу історичного твору на читача. Ігнорувалося те, що на відміну від інших наук, історичний твір мусить бути цікавим і привабливим не тільки для професіоналів, але й для пересічного читача. На жаль, не дуже далеко ми відійшли від цього і в наступні часи.

Дотримання принципу історизму перетворює соціальноекономічну та політичну історію на історію минувшини. Цьому принципові слід приділяти основну нашу увагу. На відміну від слідування іншим принципам, необхідно застосовувати для цього не тільки наукові, але й художні методи. Серед них: виділення характерних особливостей, рис, символів певного історичного періоду і місця подій; виписування дрібних деталей та використання мовних фразеологізмів, діалектизмів і окремих слів, що живлять мову дослідника минулого; цитування історичних документів; створення художніх образів минулого тощо. До речі, все це було в арсеналі великих майстрів історичної художньої літератури - Вальтера Скотта, Болеслава Пруса, Миколи Гоголя, Льва Толстого, Тараса Шевченка та ін. Гадаємо, історику не гріх постійно вчитися у них зображенню неповторного історичного колориту. Адже історична творчість - це не тільки наука, але й синтез науки і мистецтва, а тому має відповідати також принципу художності. Подібно до того, як, наприклад, гра в шахи, як загально відомо, поєднує в собі і спорт, і мистецтво. Принаймні так сприймали зазначені культурні феномени великі історики й шахісти.

У своїй основній науковій іпостасі історія має встановлювати істину, а в якості мистецтва - вчити людей добру, пробуджувати в них благородні почуття, прагнення дотримуватися священих Заповідей Божих як у повсякденному житті, так і в науковій діяльності. Зокрема, у вигляді наріжних методологічних принципів: доброчесності, верховенства істини, всебічності, системності, конкретності, об'єктивності, діалектики, історизму, художності. Отже, у певному сенсі історичні принципи виступають як різні грані ідеалу, до якого слід прагнути історику. 


\section{БІБЛІОГРАФІЧНІ ПОСИЛАННЯ}

1. Барг М. А. Категории и методы исторической науки / М. А. Барг. - М.: Наука, 1984. - 344c.

2. Биск И. Я. Методология истории: курс лекций / И. Я. Биск. - Иваново: ИГУ, 2007. - 236с.

3. Вересаев В. В. Невыдуманные рассказы о прошлом / В. В. Вересаев // Собр. соч: в 4 т. - Т.4. - М.: Правда, 1985. - С. 339.

4. Етичний кодекс ученого України, прийнятий на Загальних зборах НАНУ 15 квітня 2009 р. - Режим доступу: www.znu.edu.ua/etychnyj-kodexuchenogo-ukrajiny.pdf.

5. Ибсен Г. Враг народа. Пьеса в 5-ти действиях / Г. Ибсен // Собр соч.: в 4 т. - М.: Искусство, 1957. - Т. 3. - С. 530-632.

6. Житие протопопа Аввакума. - Режим доступу: old-russian.chat. $\mathrm{ru} / 12$ avvak.htm.

7. Закон Божий. Видання третє. - Київ: Видавничий відділ Православної церкви Київського Патріархату, 2003. - 655 с.

8. Карамзин Н. М. История Государства Российского. Репринт.воспроизведение издания пятого, 1842-1844 гг., выпущенного в трех книгах / Н. М. Карамзин. - М.: Книга, 1988. - Кн.1. - Т. 1. -155 с.

9. Ключевский В. О. Методология русской истории. 1884/85 академический год // Соч.: в 9 т. - Т. VI (Специальные курсы) / В. О. Ключевский; под ред. В. Л. Янина. - М.: Мысль, 1989. - С. 5-93.

10. Ковальченко И. Д. Методы исторического исследования / И. Д. Ковальченко // Отделение историко-филологических наук. 2-е изд., доп. - М.: Наука, 203. - 486 с. 11. Коломийцев В. Ф. Методология истории (от источника к исследованию) / В. Ф. Коломийцев. - М.: РОССПЭН, 2001. - 191 с.

12. Литвин В. М. Обвинения в плагиате - это «удар туда, куда вы подумали». - Режим доступу: focus.ua/country/199102.

13. Любавский М. К. Русская история от Скифии до Московии / М. К. Любавский. - М.: Эксмо: Алгоритм, 2012. - 384 с.

14. Могильницкий Б. Г. Введение в методологию истории / Б. Г. Могильницкий. - М.: Высшая школа, 1989. - 175 с.

15. Носовський Г. В. Русь и Рим. Правильно ли мы понимаем историю Европы и Азии? / Г. В. Носовський, А. Т. Фоменко: в 2 кн. - Кн. 1. - М.: Олимп; ООО «Фирма»; Изд-во АСТ, 1999. - 608 с.

16. Полуденный Ю. Великой Октябрьской социалистической революции не было. Доказательство // 2000. - 2017. - 20 октября. - С. 68.

17. Топ-5 політичних плагіаторів України // «Тиждень.UA». - 2011. - 2 вересня. - Режим доступу: tyzhden.ua/news/29927.

19. Санцевич А. В. Методика исторического исследования / А. В. Санцевич; АН УССР, Институт истории. - 2-е изд., перераб., доп. - Киев: Наук. думка, 1990. - 210 с. 19. Черненко А. М. В. И. Ленин об исторической общности судеб русского и украинского народов / А. М. Черненко // Историческое воссоединение Украины с Россией: Материалы юбилейной научной сессии (11-13 января 1979 г.). - Днипропетровск: Промінь, 1979. - С. 30-31.

20. Черненко А. М. Українська національна ідея / А. М. Черненко. Дніпропетровськ: ДДУ, 1994. - 144 с. 
21. Яворницький Д. І. Історія запорозьких козаків: у 3 т. / Д. І. Яворницький. - Київ: Наук. думка, 1990-1993. - Т. 3. - 415 с.

22. Corothers T. Civil Society / T. Corothers // Forein Polisy. - № 117, Winter 1999-2000. - P. 18-29.

Надійшла до редкол.: 19.11.2017

\section{Історична і соціальна пам'ять: спільне та особливе} Ковальська-Павелко І. М.

Дніпровський національний університет імені Олеся Гончара

Встановлено, що на початкових етапах становлення меморіальних концептів історичну і соціальну пам'ять здебільшого ототожнювали, вважаючи їх зрізами колективної пам'яті, проте поступово почало викристалізовуватися розуміння можливості і потреби в проведенні демаркації між даними концептами.

Ключові слова: колективна пам'ять; історична реконструкція; соціальна пам'ять; історична пам'ять; типи; форми; рівні соціальної пам'яті; соціальна амнезія

Установлено, что на начальных этапах становления мемориальных концептов историческую и социальную память в основном отождествляли, считая их срезами коллективной памяти, однако постепенно начало выкристаллизовываться понимание возможности и потребности в проведении демаркации между данными концептами.

Ключевые слова: коллективная пам'ять; историческая реконструкція; социальная память; историческая пам'ять; типы; формы; уровни социальной памяти; социальная амнезия

It was established that in the initial stages of the formation of memorial concepts historical and social memory was mostly identified, considering them as a cut of collective memory, but gradually began to crystallize the understanding of the possibility and need for demarcation between these concepts. It is stated that today it is accepted to define social memory as a form of translation of the symbolic capital of certain social groups; she is the spokesman for group values, ideas, guidelines and in this sense acts as the bearer of the norms and values of social groups, accumulates and retains social capital and ensures its use in the processes of communication and reproduction of accumulated social information, and historical memory - as a set of pre-scientific, scientific, quasi-scientific and non-scientific knowledge and mass representations of society about the common past. 